WORKING PAPERS

Macroeconomic Adjusiment and Growth

Country Eonomics Dopartmont

The World Bank

October 1991

WPS 787

\title{
Private Investment Under Macroeconomic Adjustment in Morocco
}

\author{
Klaus Schmidt-Hebbel \\ âiuú \\ Tobias Muller
}

Fiscal stabilization, a consistent foreign debt policy, more investment in public infrastructure, and a reform of investment codes would increase private investment and growth in Morocco. And reform of the financial sector. by making financial intermediation more efficient, could improve the quality of investment. 


\section{WORKING PAPERS}

Macroeconomic Adjustment and Growth

WPS 787

This paper - a product of the Macrocconomic Adjustment and Growth Division, Country Economics Department - - is part of a larger effort in PRE to understand the behavior of private investment in devcloping countries. Copies are available free from the World Bank, $1818 \mathrm{H}$ Strcet NW, Washington DC 20433. Please contact Susheela Jonnakuty, room N11-039, extension 39074 (40 pages). October 1991.

A significant domestic counterpart of Morocco's vigorous external adjustment in the cighties was a decline in fixed capital formation, of which the private sector bore a sizable share.

Schmidt-Hebbel and Muller focus on the causes of declining private investment and on the policies required to reverse this trend. Using an eclectic framework, they econometrically determine the main determinants of private investment in Morocco.

They conclude that the main causes of the decline of private investment in Morocco in the cighties were great uncertainty about policy (proxied by foreign debt), a rapid rise in the cost of capital, a more stringent credit policy, and reduced public capital

They funher conclude that fiscal stabilization, a consistent foreign debt policy, more investment in public infrastructure, and a reform of investment codes would increase private investment and growth in Morocco.

Moreover, referm of the financial sector even if it would not necessarily increase total resources available for investment - could sigrifical'y improve the efficiency of financial intermediation and therefore the quality of investment in Morocen.

The PRE Working Paper Series disseminates the findings of work under way in the Bank i Policy, Rescarch. and Exkrnal

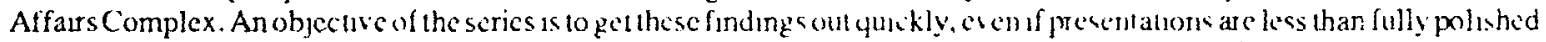
The findings, interpretations, and conclusions in these papers do not necessanly represent official Bank poilcy. 


\section{CONTENTS}

\section{INTRODUCTION}

2. PRIVATE AND PUBLIC INVESTMENT IN MOROCCO: MEASUREMENT PROBLEMS AND BEHAVIORAL PATTERN

2.1 Investment in Morocco and Other Highly Indebted Countries

2.2 Major Trends in Investment-Saving Poilances

2.3 Constant-Price Private Investment

3. THE BEHAVIOR OF PRIVATE INVESTMENT, 1970-1988

3.1 A Framework for Private Investment

3.2 Major Private Investment Determinants

3.3 Aggregate Private Investment Behavior

\subsubsection{Estimation Results}

3.3.2. Why did Investment Fall in the Eighties? An Ex-post Simulation

3.4 Private Investment Behavior by Sectors of Origin

4. CONCLUSIONS AND POLICY IMPLICATIONS

4.1 Main Findings

4.2 Policy Implications

\section{REFERENCES}

\section{APPENDIX A: A METHODOLOGICAL NOTE ON THE PRIVATE INVESTMENT SERIES}

APPENDIX B: THE REAL USER COST OF CAPITAL

APPENDIX C: MOROCCO DATA SERIES (1970-1988)

-This paper originated from collaboration with EM2CO on Morocco country work. We thank Isabel Guerrero, country economist for Morocco, for very valuable comments and support. We are also indebted to Alberto Antonini, Bela Balassa, Ajay Chhibber, Mansoor Dailami, and Bernard Ziller for useful comments. 


\section{INTRODUCTION}

Morocco went through a major macroeconomic and external adjustment during the eighties, drastically reducing its current account deficit, from $12.3 \%$ of GDP in $1981-82$ to zero in 1988 . The demestic counterpart of this adjustment was a major increase in gross national saving, which rose from $14.9 \%$ of GDP in $1981-82$ to $22.6 \%$ in $1987-88$, and a significant decline in gross fixed capital formation, from $26.7 \%$ to $20.2 \%$ during the same period. This sizeable investment decline has serious implications for future growth.

An important share of the adjustment effort was borne by the private sector. While private saving increased from $20.8 \%$ of GDP in $1981-82$ to $23.5 \%$ in $1987-88$, private fixed capital formation dropped from $19.2 \%$ to $16.2 \%$. Due to the huge real exchange rate depreciation after 1980 - which supported the external adjustment - the levels and the decline in the constant-pricr private investment rate are even more dramatic: it fell from $17 \%$ in $1981-82$ to $13.4 \%$ in $1987-88$.

The purpose of this paper is to identify the main determinants of private capital formation in Morocco. ${ }^{1}$ This will help to derive implications for policies supportive of higher investment efforts required for a path of high and sustainable growth.

Section 2 describes the performance of private and public investment during 1970-1988. The next section presents a framework for private investment, reviews the evolution of its main determinants, and presents econometric estimates of private investment functions covering the period 1970-1988. Section A summarizes the main findings and draws policy implications.

(1990).

\footnotetext{
${ }^{1}$ An analysis of private sector saving in Morocco is carried out in Schmidt-Hebbel and Müller
} 


\section{PRIVATE AND PUBLIC INVESTMENT IN MOROCCO: MEASUREMENT PROBLEMS AND BEHAVIORAL PATTERN}

This section reviews the evolution of private and public investment rates during the last two decades. Assessing Morocco's investment record both over time and in comparison to other countries suggests patterns and puzzles which are analyzed more systematically in the following section.

One word of caution is in order. Due to limitations of data availability discussed at length in Appendix A, national saving and total gross domestic investment could only be broken down into two sector categories: general government ${ }^{2}$ and private sector (including public enterprises). In the following pages, the words public and private refer to this particular breakdown, e.g. public sector capital stock means government sector capital stock. ${ }^{3}$

\subsection{Investment in Morocco and Other Highly Indebted Countries}

Investment rates have shown large fluctuations over the last two decades in Morocco. Compared to 12 other highly indebted countries $(\mathrm{HICs})^{4}$, the evolution of Morocco's investment rate shows similarities, but also distinctive features that raise questions (see figuri 2.1).

${ }^{2}$ General government is defined as the aggregate of the central government (budget général, budgets annexes, comptes spéciaux du trésor), local administrations, public non profit organizations (e.g. universities, hospitals), and the social security system.

${ }^{3}$ This definition of the private sector, encompassing public enterprises, forces to be cautious in drawing conclusions from the data. However, the variability in the investment sample is large enough not to depend too much on public enterprise investment, which accounted for only $28 \%$ of nongovernment investment in 1980-82. Appendix A discusses some limited evidence on the evolution of "pure" private and public enterprise investment.

The World Bank groups 17 countries as highly indebted countries. Private (and total) investment rates are published by Pfeffermann and Madarassy (1989) for 12 of them, i.e. Argentina, Bolivia, Brazil, Chile, Costa Rica, Ecuador, Mexico, Nigeria, Peru, Philippines, Uruguay, and Venezuela. When comparing private investment rates in the HICs with those for Morocco, one has to bear in mind that the latter includes public enterprise investment, whereas the HICs data does not for most countries. For this comparison investment rates at current prices are used for all countries. 
The broad trends are similar: an increase of the investment rate until the late seventies and a clear decline in the eighties with the outbreak of the debt crisis. The differences occur (i) between 1975 and 1977, when both total and private investment rose to very high levels in Morocco, and (ii) after 1985, when investment picked up in the other HICs, but not in Morocco. However. in 1987 the ratio of total investment to GDP (at current prices) was still higher in Morocco than in the other HICs.

This simple comparison raises two questions with important policy implications: why did the private investment rate fall in the eighties in Morocco, and why did private investment not respond earlier to the new incentive structure created by structural reforms, as in other HICs?

The following paragraphs illustrate and comment on the historical evolution of investment and saving in Morocco, without trying to answer the questions raised above. Some answers will be given in the light of the econometric results in sections 3 and 4 .

\subsection{Major Trends in Investment-Saving Balances}

Two general observations can be drawn from the recent evolution:

(i) Private and public investment seem to be highly correlated (see Figure 2.1). This cannot be entirely explained by the fact that private investment includes public enterprises, as the latter account for less than a third of non-government investment. It may reflect a strong complementarity between public and private investment; or it can indicate that similar financing constraints apply to both. This hypothesis will be ieflected by the specification below.

SThere are some indications, such as investment permits given to the manufacturing sector, that private industrial investment has finally started to recover in Morocco in 1989. 
Figure 2.1

Private and Total Fixed-Capital Investment in Morociso and 12 Highly Indebted Countries

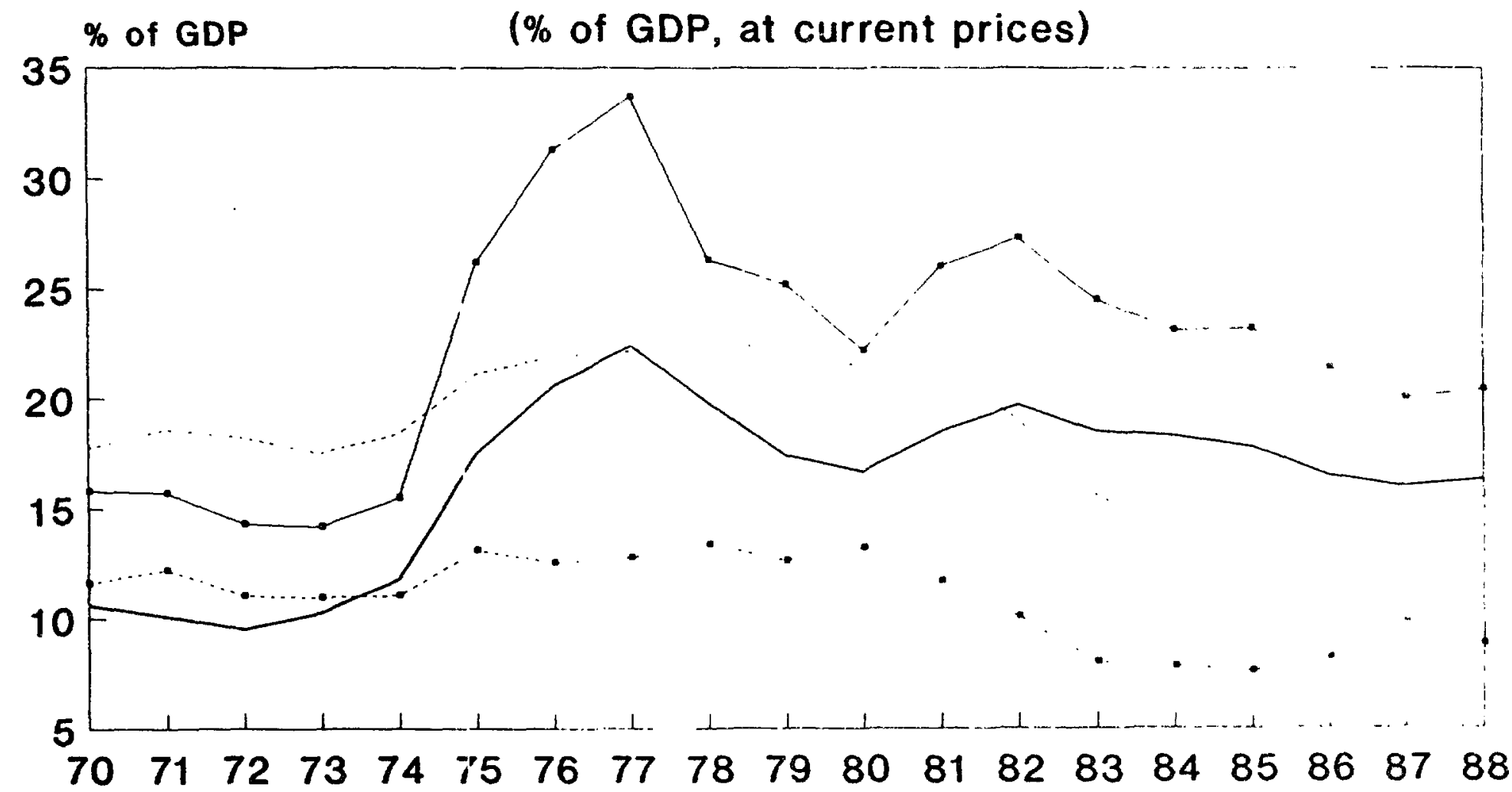

- Morocco: Private Investment/GDP - Morocco: Total Investment/GDP

..... 12 HICS: Private Investment/GDP 12 HICS: Total Investment/GDP 
(ii) Figure 2.2 illustrates the current-price saving-investment balance for the economy ${ }^{6}$. It shows that both the public and private sectors contributed to the significant external adjustment whic:. took place since the mid-eighties.

The evolution of investment and saving rates should aiso be seen in the context of external developments and domestic economic policy decisions.

In the early seventies private investment (fixed capital formation) and saving rates were relatively low, about $10 \%$ and $16 \%$, respectively. The 1973-74 oil and phosphate price shocks led to a strong increase in private saving, which was partially reversed thereafter. However, private saving remained during 1975-1981 at levels 5 percentage points of GDP higher than those of the early seventies.

From 1975 to 1977 an unprecedented boom in investment rates ocsurred due to the simultaneous impact of three factors. First, the 1973-1977 five-year plan had already set ambitious targets for public investment. Second, the sudden rise of phosphate prices in 1974, as well as Morocco's claim on the Western Sahara, led to an upward revision of the investment targets. Finally, the private investment rate more than doubled between 1973 and 1977. The government deficit rose massively and tủe private saving-investment surplus shrunk. Foreign saving therefore reached an all-time high of $15.7 \%$ of GDP in 1977.

The following 1978-1980 three-year plan aimed at reestablishing macroeconomic balances. The goyernment deficit was reduced and public and private investment rates fell to $6 \%$ and $17 \%$ respectively.

Public investment was slightly revived in the first two years of the 1981-1985 plan, while public saving deteriorated significantly. The ensuing rise in the public deficit was reflected in a similar current account deterioration which, in combination with the 1982 inte suational debt crisis, led to Morocco's

Gee also Table C.1 in the Appendix. 
Figure 2.2

\section{Morocco: Saving - Investment Balance}

(\% of GDP, at curreni prices)

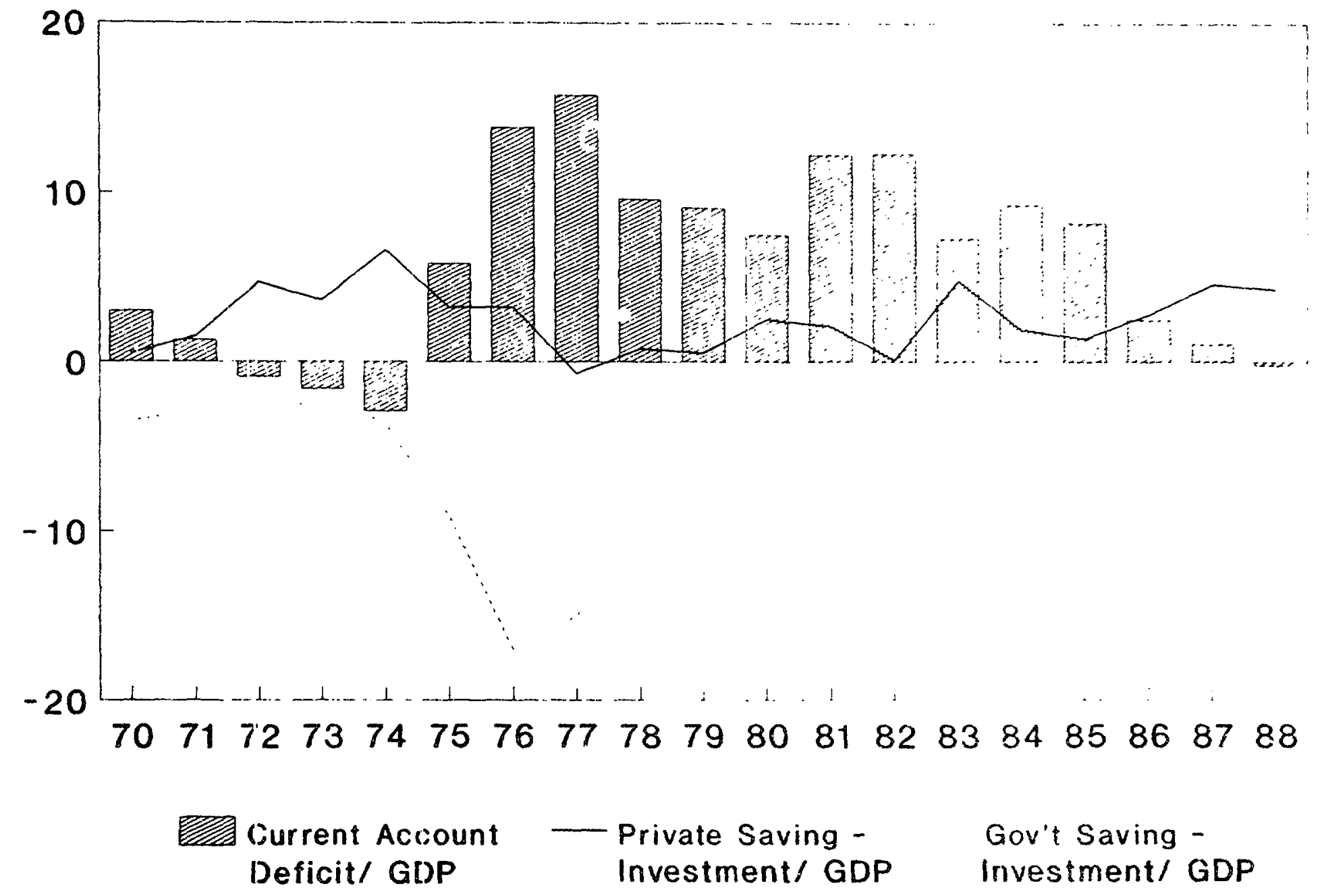


1983 balance of payments crisis. No longer being able to finance its current account deficit, the country implemented a stabilization program with assistance from the IMF and the World Bank. On the basis of the IMF stand-by programs the government obtained successive rescheduling of its foreign debt.

The strong adjustment effort carried out since 1983 combined expenditure-switching measures based mainly on devaluations with fiscal expenditure-reducing policies. They resulted in continuous improvements in both public and current account deficits during 1982-88 -- Morocco, in fact, achieved a slight current account surplus in 1988. However, both private and public investment levels bore a significart share of this adjustment effort.

\subsection{Constant-Price Private Investinent}

When interpreting the time series for the private investment rate, one has to bear in mind the importance of the investment deflator. The real depreciation of the Dirham between 1980 and 1985 drove a wedge between the GDP and the investment deflator, reflecting the high share of imported goods in investment. Thus the evolution of private investment appears in a different light whether it is evaluated at current or constant prices. However, the relevant indicator for measuring the increase in the capital stock is the investment rate measured at constant prices.

Constarit-price private investment, as illustrated by figure 2.3 , fell from $17 \%$ in $1981-82$ to $13 \%$ of GDP in 1988. In addition, machinery and equipment decreased their share in total private investment, from $43 \%$ (or $7.3 \%$ of GDP) in $1981-82$ to $36 \%$ (or $4.7 \%$ of CDP) is 1308 . This leads to the conclusion that productive investment has fallen even more than total fixed capital formation in Morocco during the 1980s. 
Figure 2.3

Morocco: Private Fixed-Capital Investment and its Composition

(\% of GDP, at constant 1980 prices)

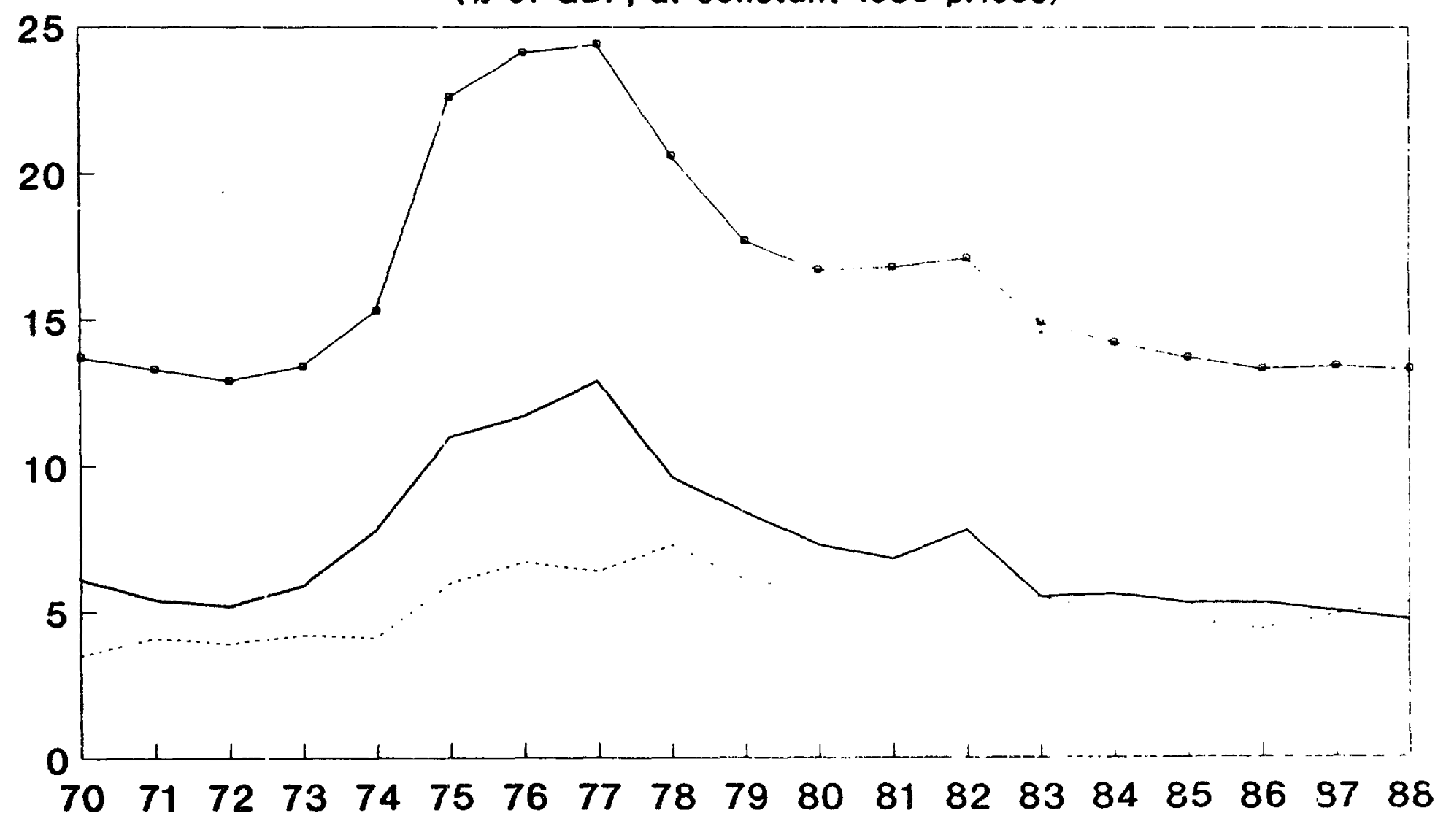

$\rightarrow$ Priv Fixed-Capital

- Priv Investment in Machinery and

Priv Investment Investment/ GDP Equipment/ GDP 


\section{THE BEHAVIOR OF PRIVATE INVESTMENT, 1970-1988}

\subsection{A Framework for Private Investment}

The specification of the private investment and saving functions will draw from the recent empirical literature on investment behav: $\mathrm{u}$ with appropriate consideration of the structural features of the Moroccan economy. The relevant recent work on which the investment specification will be based includes the survey by Serven and Solimano (1990) and empirical studies by Chhibber and Shafik (1990), Dailami (1990a, 1990b), Dailami and Walton (1989), De Melo and Tybout (1990), Faini and De Melo (1990), Greene and Villanueva (1990), Kahn and Reinhart (1990), Musalem (1989), Schmidt-Hebbel (1987), and Solimano (1989). Partic ar emphasis is given to the role of public policy-related variables, as put forth by Easterly et al. (1989) and Easterly and Schmidt-Hebbel (1991). Among them are cirect fiscal policy variables, such as taxes and public investment, and financial variables such as interest rates and credit flows.

The specification of the investment function is not derived from first principles. To reduce the incidence of problems derived from spurious correlation and non-stationarity of both dependent and independent variables, rates of GDP instead of absolute levels are specified for private fixed-capital investment (constant-pice private investment as a fraction of constant-price GDP) and all reievant righthand scale variables.

The framework for private investment combines neoclassical investment determinants (the user cost of capital and the marginal product of capital) with borrowing constraints (credit to the firms, foreign resources), public infrastructure (reflecting public/private capital complementarity), and uncertainty variables (the variances of output and the user cost of capital, and the foreign debt to output ratio).

The simultaneous presence of financial price (interest) and quantity variables describes a situation of segmented credit markets where ceilings are imposed on certain categories of credit by the deposit banks. Export credits and loans extended by the specialized financial institutions are exempt from the 
ceilings; but these credits are not available to all firms. Due to partial financial liberalization during the eighties, the relative importance of quantity constraints has probably diminished over time while the relevance of the user cost of capital has been increasing. ${ }^{\text {? }}$

In a highly indebted country undergoing far-reaching structural reforms, uncertainty over the sustainability of the current policy framework is a major hindrance to private investment, due to the irreversibility of investment decisions. ${ }^{8}$ Unlike risk linked to a stochastic behavior of prices and economic activity, uncertainty over economic policy is not only perceived on the basis of past variability of these variables. It arises in situations where economic policy is not credible or judged not to be sustainable. In a recent paper, Rodrik (1989) shows that even small probabilities of policy reversal in a modal with entry and exit costs for capital can deter private investment by considerable amounts.

The specification used in this paper, in accordance to the referred literature, considers five groups of investment determinants: neoclassical and Keynesian variables, borrowing constraints, public infrastructure, uncertainty variables, and relevant lags. The generic form of the equation is the following, with expected signs of the partial derivatives denoted below each variable:

However, due to the small size of our sample our application will be restricted to fixedcoefficients estimations.

Tor the role of uncertainty in irreversible investment decisions see Bernanke (1983), Bertola (1989), Bertola and Caballero (1990), Bizer and Sichel (1988), and Pindyck (1988, 1989). 
(1)

$$
\begin{array}{r}
\frac{I_{P t}}{Y_{t}}=\frac{I_{P}}{Y}\left(U C K_{t}, \frac{Y_{t}}{Y T_{t}}, \frac{F C}{Y_{t}}, \frac{T T_{t}}{Y_{t}}, \frac{N D_{t}}{Y_{t}}, \frac{K G_{t}}{Y_{t}}, V U C K_{t}, V Y_{t}, \frac{D_{t}}{Y_{t}}, \frac{I_{p x-1}}{Y_{t-1}}\right) \\
(-)(+)(+)(+)(+) \quad(+) \quad(-) \quad(-)(-) \quad(+)
\end{array}
$$

The private fixed-capital investment to GDP ratio $\left(I_{P} / Y\right)$ in equation (1) depends in the first place on two variables related to neoclassical/Keynesian hypotheses. Investment is affected negatively by the user cost of capital (UCK) and positively by the ratio between current and trend GDP levels (Y/YT). The user cost of capital reflects the interest rate, relevant business taxes, tax credits and depreciation allowances as well as the replacement cost of capital goods and its expected rate of change? The ratio of actual and trend GDP is a proxy for both the marginal product of capital (which together with UCK represents the traditional neoclassical investment determinants ${ }^{19}$ ) and capacity utilization (an investment determinant in Keynesian analyses). ${ }^{11}$

The flows of banking sector credit to private firms (FC), terms of trade (TT) and net foreign disbursements to firms (ND) are variables which represent the influence of domestic and foreign credit constraints to investment. An increase in any of them relaxes borrowing constraints faced hy private

'A cetailed calculation of the rial user cost of capital for Morocco, based on Faini and Pigato (1989), is in Appendix B.

${ }^{10}$ The reason for choosing as the relevant neoclassical variables the 1:cop cost of capital cum marginal product of capital specification instead of a proxy for Tobin's $q$, is wat the latter would be the ratio between the stock market index and the replacement price of capital goods. However, Morocco has a very thin stock market, through which only an insignificant proportion of private investment is financed.

"The marginal product of capital is a linear function of the output/capital ratio with a Cobb-Douglas production funcsion. If the capital stock is proportional to trend output, then the ratio of actual to trend GDP is a good proxy for the marginal product of capital. 
firms as a result of controlled interest rates and regulations on sectoral credit allocations, widely observed in Moroccan financial markets.

Public infrastructure, colımunications and transport services are often underpriced with long waiting times and other administrative measures which inhibit both efficient use by the private sector and lead to sub-optimal public investment levels in these areas. This contributes to rationing of public services with very high urban land prices in areas which have access to the rationed public services. Increased availability of public services through higher public investment raises the profitability of private investment. Crowding in of private investment in response to public investment in infrastructure (due to complementarity of private and public infrastructure capital for private production) is captured by the stock of public sector capital (KG) ${ }^{12}$

Two sources of risk and uncertainty inhibiting or postponing private investment can be identified. One refers to the risk associated with economic variables that are important determinants of private investment, such as GDP and the user cost of capital. This phenomenon is captured in our specification by the moving variances of GDP (VY) and the user cost (VUCK).

The other refers to the uncertainty over potential future policy reversals. In this case, uncertainty is caused by low credibility of the current policy framework, which induces a postponement of the investment decision. We have approximated this policy uncertainty by one variable which strongly contributes to it, without being its only determinant: the external debt to GDP ratio (D/Y). In addition

\footnotetext{
${ }^{12}$ As opposed to most other studies on private-public investment complementarity, where current-period public investment is specified to crowd in current-period private investment, here it is the end-of-preceding period public sector capital stock which potentially affects current period private investment positively.
} 
and separately, this variable signals the negative "debt overhang effect" on private investment, due to higher expected future taxes required to service foreign debt payments. ${ }^{13}$

Finally, the one-period lagged investment rate substitutes for all relevant lagged independent variables, which affect current capital formation when capital installation lags are present.

\subsection{Major Private Investment Determinants}

This section describes the historical evolution of the major private investment determinants (see section 4.1). The data for all explanatory variables used in the estimations can be found in Appendix C.

The user cost of capital depends on the lending interest rate, depreciation allowances, the tax regime, and the level and rate of change of the price of capital goods (See Appendix B). An increase in the current-period price level has two opposite effects on the user cost: it signals an expected capital gain and lowers the real user cost in the current period, whereas the higher level implies an increase in the real price of capital goods. The first effect prevails in the short run while the second is more important in the longer run.

The real cost of capital fell from $8 \%$ in $19 ; 0$ to $-8 \%$ in 1983 . Then it increased extremely rapidly to more than $20 \%$ in $1986-1988$. This evolution is due to the conjunction of several factors: (i) the increase in nominal lending interest rates from $8 \%$ in 1970 to $14 \%$ in 1988 , (ii) a slowdown in the expected growth rate of the price of investment goods after 1983, reiniorced by a reduction of import tariffe, and (iii) a reduction of the business tax rate in the Tanger reginn in 1983.

The ratio of current to trend GDP is influenced, among other factors, by agricultural output, which is very volatile due to rain fluctuations in Morocco. Therefore the good harvests in 1986 and 1988

${ }^{13} \mathrm{~A}$ significant negative influence of outstanding foreign debt on private investment is estimated for Brazil by Schmidt-Hebbel (1990) and reflected by debt-conversion simulations for the same country by Schmidt-Hebbel and Vatnick (1990). 
are represented by peaks. Aggregate demand has strong transitory effects on output: the spending boom in the second half of the seventies was reflected by high actual to trend GDP ratios.

Morocco is an important phosphate rock and fertilizer exporter and imports all of its oil. Its terms of trade gains reached a maximum of $4 \%$ of GDP in $1974 / 1975$, when phosphate prices had increased far more than oil prices. The subsequent collapse of phosphate prices brought the terms of trade back to the initial level. After a further deterioration until 1984/1985, the oil price decline improved Morocco's terms of trade between 1986 and 1988.

Credit to the private sector had been growing steadily, from $15 \%$ of GDP in 1970 to $24-25 \%$ in 1983. Tighter monetary policy after the foreign exchange crisis has stabilized the credit to GDP ratio since then.

The government capital stock increased from 50\% of GDP in 1970 to almost $90 \%$ in $1981 / 1983$. As a consequence of the reduction in government investment during the stabilization period, it decreased to $75 \%$ of GDP in 1988 .

The debt to GDP ratio, stable and low until 1975/1976, increased subsequently, because Morocco had to finance its ambitious investment program from foreign sources. As described in section 2.2 , the current account deficit could not be decisively reduced before $1985 / 1986$. Consequently, the debt to GDP ratio grew until those years, starting a slight decline in $1987 / 1988$.

\subsection{Aggregate Private Investment Behavior}

\subsubsection{Estimation Results}

Linear forms for equation (1) for aggregate private investment were estimated for the Moroccan economy on annual data covering the 1970-1988 period. The empirical results are presented in table 3.1.

The small sample size forces caution in interpreting these results. No single best estimation has been selected, because of collinearity among right-hand variables, which affects the significance levels 
of individual variables. Equation 1.1 in table 3.1 presents the complete specification comprising most variables present in equation (1) above. Variable DU is a dummy for the high-investment period 1975 1978, during which both private and public investment reached abnormal high values not accounted for by other determinants; during those years the rate of private investment exceeded normal levels by 5 percentage points, as reflected by the coefficient of $\mathrm{DU}^{14}$.

Equation 1.2 in table 3.1 is the two-stage least squares (2SLS) version of equation 1.1, specified to instrumentalize the lagged dependent variable. In both equations 1.1 and 1.2 the lagged endogenous variable, net foreign disbursements to firms, and the variance of the user cost of capital are not individually significant at acceptable statistical levels. Equations 1.3 and 1.4 omit in stages these variables. These three variables are also not jointly significant as was inferred from the corresponding F-tests.

The cost of capital and the government capital stock are not significant at acceptable levels in equations $1.1-1.4$, which seems to be mostly a reflection of the high collinearity between these two variables and the debt to GDP ratio. In fact, when deleting the government capital stock from equation 1.6, the user cost of capital is significant. Although the negative influence of the cost of capital on investment has a low magnitude, its effect on private capital formation has probably been growing over time, as rising interest rates have weakened the influence and extent of credit or quantity constraints.

Equations $1.4-1.6$ show robust results for a number of investment determinants ${ }^{15}$.

${ }^{14}$ There are clear indications that public enterprise investment, included in private investment, was very important during that period.

${ }^{15}$ Because of the above-mentioned multicollinearity between three important variables, these equations should not be discussed separately. Taken on its own, one equation does not reflect well ine influence of all variables. 
TABLE 3.1

AGGREGATE PRIVATE INVESTMENT IP/D

(1970-1988)

\begin{tabular}{|c|c|c|c|c|c|c|c|c|c|c|c|c|c|c|c|}
\hline \multicolumn{2}{|c|}{ Equation } & c & UCK & Y/rT & $\underline{\mathrm{FC} / Y}$ & $\underline{\operatorname{TT} / Y}$ & $\mathrm{ND} / \mathrm{Y}$ & $\underline{\mathbf{K G} / \mathbf{Y}}$ & VUCK & $\underline{D} / Y$ & $\underline{\mathrm{DU}}$ & $\mathbf{P} / \mathbf{Y}(-1)$ & Dw & $\mathbf{R}^{2} \mathbf{A}$ & $\mathbf{E}$ \\
\hline \multirow[t]{2}{*}{1.1.} & LS & -0.20 & -0.05 & 0.24 & 0.82 & 0.38 & 0.31 & 0.09 & -0.14 & -0.18 & 0.05 & -0.25 & 2.12 & 0.94 & 30.2 \\
\hline & & $(-1.3)$ & $(-0.9)$ & (1.7) & (2.4) & $(1.7)$ & (1.1) & $(0.8)$ & $(-1.2)$ & $(-2.1)$ & (3.7) & $(-1.0)$ & & & \\
\hline \multirow[t]{2}{*}{1.2.} & SLS* & -0.24 & -0.05 & 0.27 & 0.85 & 0.34 & 0.33 & 0.12 & -0.14 & -0.20 & 0.05 & -0.35 & 2.29 & 0.94 & 29.7 \\
\hline & & $(-1,4)$ & $(-0.8)$ & (1.8) & (2.5) & (1.5) & (1.1) & (1.0) & $(-1.3)$ & $(-2.2)$ & (3.8) & $(-1.2)$ & & & \\
\hline \multirow[t]{2}{*}{1.3.} & IS & -0.14 & -0.06 & 0.19 & 0.69 & 0.48 & & 0.04 & -0.11 & -0.14 & 0.05 & & 2.12 & 0.94 & 38.2 \\
\hline & & $(-.7)$ & $(-1.2)$ & (2.5) & $(2.1)$ & (2.5) & & $(0.5)$ & $(-1.0)$ & $(-1.8)$ & (4.4) & & & & \\
\hline \multirow[t]{2}{*}{1.4.} & LS & -0.17 & -0.06 & 0.22 & 0.67 & 0.53 & & 0.04 & & -0.13 & 0.05 & & 2.04 & 0.94 & 43.7 \\
\hline & & $(-2.1)$ & $(-1.2)$ & (3.1) & (2.1) & (2.8) & & $(0.5)$ & & $(-1.8)$ & (4.3) & & & & \\
\hline \multirow[t]{2}{*}{1.5.} & LS & -0.20 & & 0.21 & 0.71 & 0.43 & & 0.12 & & -0.19 & 0.04 & & 1.67 & 0.94 & 49.1 \\
\hline & & $(-2.6)$ & & (2.9) & (2.2) & (2.5) & & (2.3) & & $(-3.9)$ & (4.0) & & & & \\
\hline \multirow[t]{2}{*}{1.6.} & LS & -0.16 & -0.08 & 0.22 & 0.73 & 0.56 & & & & -0.11 & 0.05 & & 2.19 & 0.95 & 54.4 \\
\hline & & $(-2.1)$ & $(-2.7)$ & (3.2) & (2.5) & (3.3) & & & & $(-1.8)$ & (4.4) & & & & \\
\hline
\end{tabular}

-Instrumentelized variable: IPR/Y (-1). 
The degree of uncertainty and risk perceived by private investors was related in our analysis to both the total stock of foreign debt outstanding and the moving variances of the cost of capital and GDP. The first variable represents both a proxy of the higher risk of future macroeconomic instability and relative price changes and a signal of higher expested future taxes to service the debt. Our results show that the debt/GDP ratio is moderately significant in reducing Morocco's investment rate. The magnitude of its effect suggests that for each $10 \%$ decline in the debt/GDP ratio the investment rate could increase by some 1.5 perceatage points - a result which should not be extrapolated for major declines in debt-GDP ratios. The other two measures of risk, reflecting the uncertainty of the economic environment, were not found to affect investment rates. ${ }^{16}$

The amount of bank credit to firms plays an essential role in an economy whose financial system has been dominated by credit cellings and quantity constraints, with interest rates playing a secondary, although increasing, role in determining financial resource allocation. Not surprisingly, bank credit to firms has been a statistically and numerically important determinant of private investment in Morocco: for every percentage point increase in the credit/GDP ratio, the investment rate has increased by 0.7 percentage points. However, because of the relatively declining role of credit constraints vis- $\mathrm{a}-\mathrm{vis}$ the cost of capital, this relation is probably smaller in the present.

Capacity utilization and the marginal product of capital - both proxied by the ratio of current to trend GDP - are significant determinants of private investment in Morocco. This ratio, which reflects the economy's business cycle, probably signals also the inflụence ọ ạn impnrtant financing source of private investment: retained profits, which are correlated with the cycle. The magnitude of the business

\footnotetext{
${ }^{16}$ In fact, the results which include the variance of GDP are not presented in the table due to the negligible significance of this variable.
} 
cycle effect on investment is moderately high: for every percentage point gain of GDP relative to its trend level, the investment rate raises by 0.22 percentage points. ${ }^{17}$

Gains from terms of trade are an important determinant of aggregate private investment, as opposed to net disbursements of foreign loans to the private sector. The empirical evidence suggests a high magnitude for this effect: approximately $50 \mathrm{cts}$. of each dollar from terms of trade gains (losses) increases (reduces) investment. This effect suggests the importance of either an overreaction to transitory commodity price booms or the extent of foreign liquidity constraints, or both.

Public infrastructure, communications and transport services are very scarce though often underpriced in Morocco. This contributes to the high price of urban and industrial land (when those services are available), a major current constraint on private investment in the manufacturing sector. In our analysis we proxied the availability of infrastructure and communications by a measure of the capital stock stemming from government investment. Although its significance suggests some role played by this constraint to private investment, its magnitude is quite small.

\subsubsection{Why did Investmeni Fall in the Eighties? An Ex-post Simulation}

A question with important implications for future growth prospects is: why did the private investment rate decrease over the adjustment period, from $17.2 \%$ in $1979-1980$ to $13.3 \%$ in $1986-1988$ ? The contribution of different macroeconomic variables to this decline can be analyzed by decomposing the change in investment explained by the estimated investment equations.

The methodology for this decomposition is straightforward. We use the fitted equation of the investment rate and decompose its change over a certain period into a sum of changes due to variations of its explanatory variables.

\section{table 3.1.}

${ }^{17}$ This and the subsequent coefficients mentioned below correspond to equations $1.4-1.6$ of 
In order to get more robust results ${ }^{18}$, two different investment equations, 1.5 and 1.6 of tahle 3.1, are used for this decomposition. The fitted private investment rates (shown in figure 3.1 for equation 5.1) match the actual series quite well. Because of the estimation errors, however, the benchmark for the period over which the decline in the investment rate is analyzed, are taken as averages: 1979-1980 and 1986-1988.

Table 3.2 presents the decomposition of the private investment decline according to the contribution of its explanatory variables.

Three variables played a significant role in the fall of th private investment rate during the 1980s: the debt to GDP ratio, the user cost of capital and the ratio of current to trend GDP. The influences of the first two variables reflect their trends, whereas the third variable is by definition cyclical. The increase of the debt to GDP ratio ${ }^{19}$ (from $47 \%$ in $1979 / 80$ to $70 \%$ in 1986-88) explains over $70 \%$ of the drop in the investment rate. Thus, growing uncertainty on future policy reversals, and higher expected future taxes as proxied by the debt to GDP ratio, play an essential role in the investment decline observed during the eighties in Morocco. The sharp rise of the real user cost of capital from 0 to $24 \%$ over the same period may explain up to $50 \%$ of the investment decline. The contribution of the current to trend GDP ratio depends very much on the choice of the beginning and end cf the periodo and should therefore not be overemphasized.

The influence of the public capital stock and the terms of trade adjustment is negligible over the periüu. The ratio of the public capital stock to GDP is only slightly lower in 1986-1988 (80\%) than in 1979-1980 (o $\%$ ). Likewise, there has been no significant change in the terms of trade.

${ }^{18}$ In the presence of multicollinearity between explanatory variables (UCK, KG/Y, D/Y), the contribution of each of these variab!es cannot be clearly identified.

${ }^{19}$ The debt to GDP ratio is measured at constant prices and exchange rate.

${ }^{30}$ In 1979 and 1980, GDP was above the 20-year trend, whereas on average 1986-1988 were below, because of the negative growth in 1987 . 
Figure 3.1

Actual and Fitted Private Fixed-Capital Investmert

(\% of GDP, at constant 1980 prices)

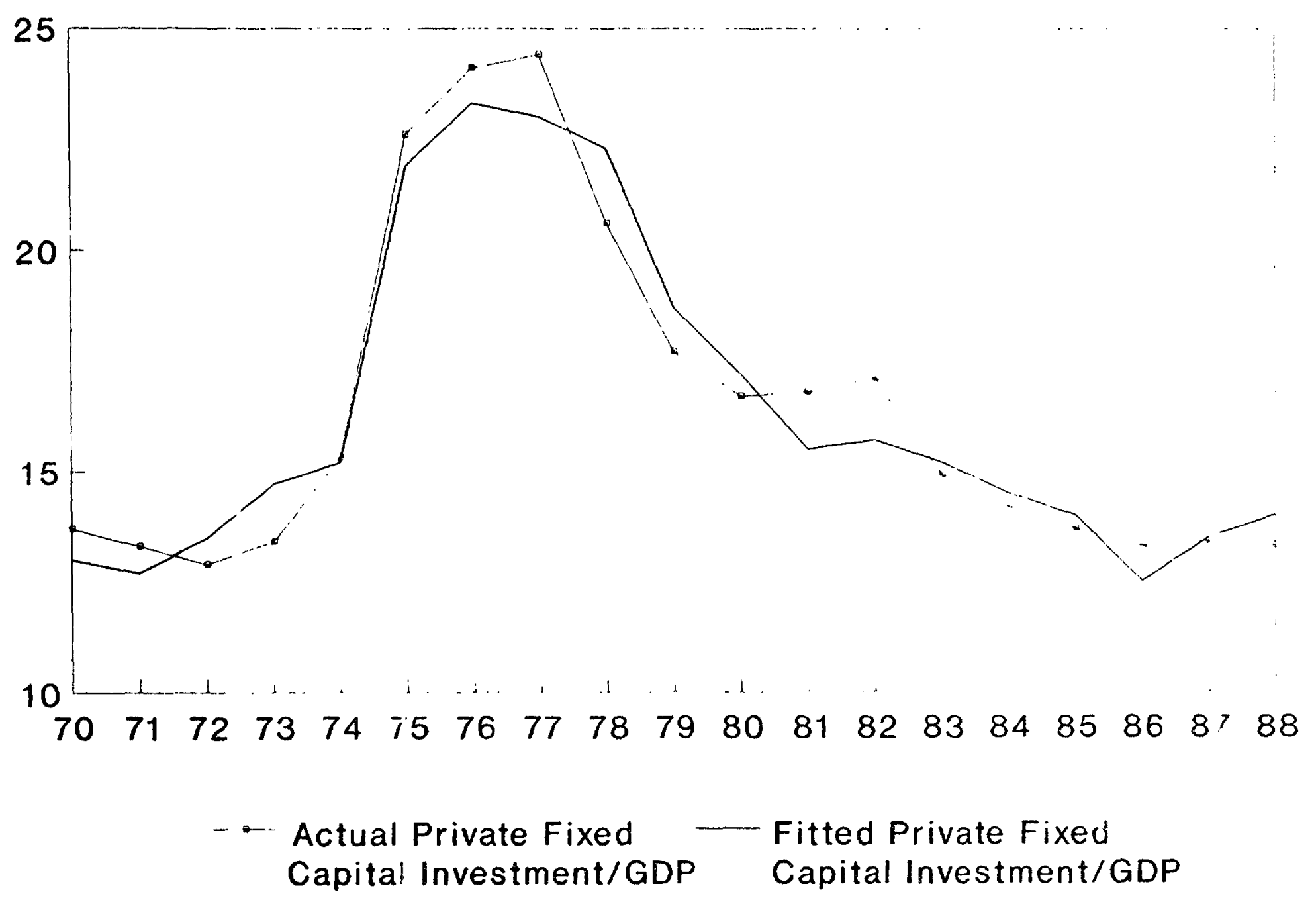


Table 3.2

CONTRIBUTION OF EXPLANATORY VARI IBI ISS TO THE DECI.ME IN THE PRIVATE INVESTMENT RATE BETWEEN 1979-1980 AND 19861988

Changes in Percentage Points of GDP (changes in \% of Private Investment Rate decline)

Based on

Equation 1.5
Based on

Equation 1.6
Foreign Debt/GDP (D/Y)

User Cost of Capital (UCK)

Public Capital Stock (KG/Y)

Firm Credit/GDP (FC/Y)

Current/Trend GDP (Y/YT)

Terms of Trade Adiust.(TT/Y)

Unexplained Variation

Private Investment/GDP (IP/Y)
$-4.6 \%(120 \%)$

$-2.7 \%(70 \%)$

$-2.0 \%(51 \%)$

$-0.2 \%(6 \%)$

$1.9 \%(-49 \%)$

$1.9 \%(-50 \%)$

$-1.5 \%(40 \%)$

$-1.6 \%(42 \%)$

$0.1 \%(-4 \%)$

$0.2 \%(-5 \%)$

$0.5 \%(-13 \%)$

$0.3 \%(-8 \%)$

$-3.8 \%(100 \%)$

$-3.8 \%(100 \%)$ 
The only variable that tended to incruase private investment is the availability of credit to private sector firms. The ratio of credit to GDP increased between $1979-1980$ and 1983 from $21 \%$ to over $24 \%$ and remained stable in the later years. This increase would have accounted for a rise in the private investment rate by 1.9 percentage points of GDP.

\subsection{Private Investment Behavior by Sectors of Origin}

Let's turn now to the behavior of private investment by sectors of origin. We concentrate on the two major components of aggregate private investment: buildings (B) and machinery and equipment (ME). Tables 3.3 and 3.4 report the main empirical results. The discussion here will focus only on the main differences between these results and those related to aggregate investment in table 3.1 .

The role of the user cost of capital relative to the price of output ${ }^{2}$ seems to be weaker at the sector than at the aggregate level. Although its individual significance level is hampered by strong collinearity with other right-hand variables, its numerical influence is very low for both investment categories.

An interesting behavioral difference between the two investment categories is that construction activity is procyclical, while ME investment depends on the level of net foreign disbursements. This difference seems to be sensible when considering that B investment includes housing construction (which is strongly correlated with the cycle in most countries), while ME is correlated with investment in manufacturing and export sectors, which typically presents a higher degree of foreign financing than housing investment.

"Note that the sector user cost of capital relative to the GDP deflator was constructed separately for investment and buildings (UCKB) and investment in machinery and equipment (UCKM), taking into consideiation the differences in taxes, depreciation rates, and investment deflators. See Appendices $B$ and $C$. 
Domestic bank credit to firms and foreign terms of trade gains are significant and numarically important determinants of both investment categories, replicating their influence on aggregate investment.

As at the aggregate level, there is only weak evidence for private sector investment crowding in from a more developed public infrastructure. While there is no evidence for the role of the public sector capital stock in determining ME investment, some influence of this variable on B investment is found. Its low magnitude suggests that private housing and plant construction will expand modestly if government investment is significantly increased.

Finally, risk variables also play a similar role in determining investment by categories and aggregate investment. The variance of the cost of capital does not have a significant role on private investment categories. However, uncertainty about future economic policy and related to high debt/output levels plays an important role in determining investment in machinery anc. equipment, and a smaller role in affecting investment in buildings. 


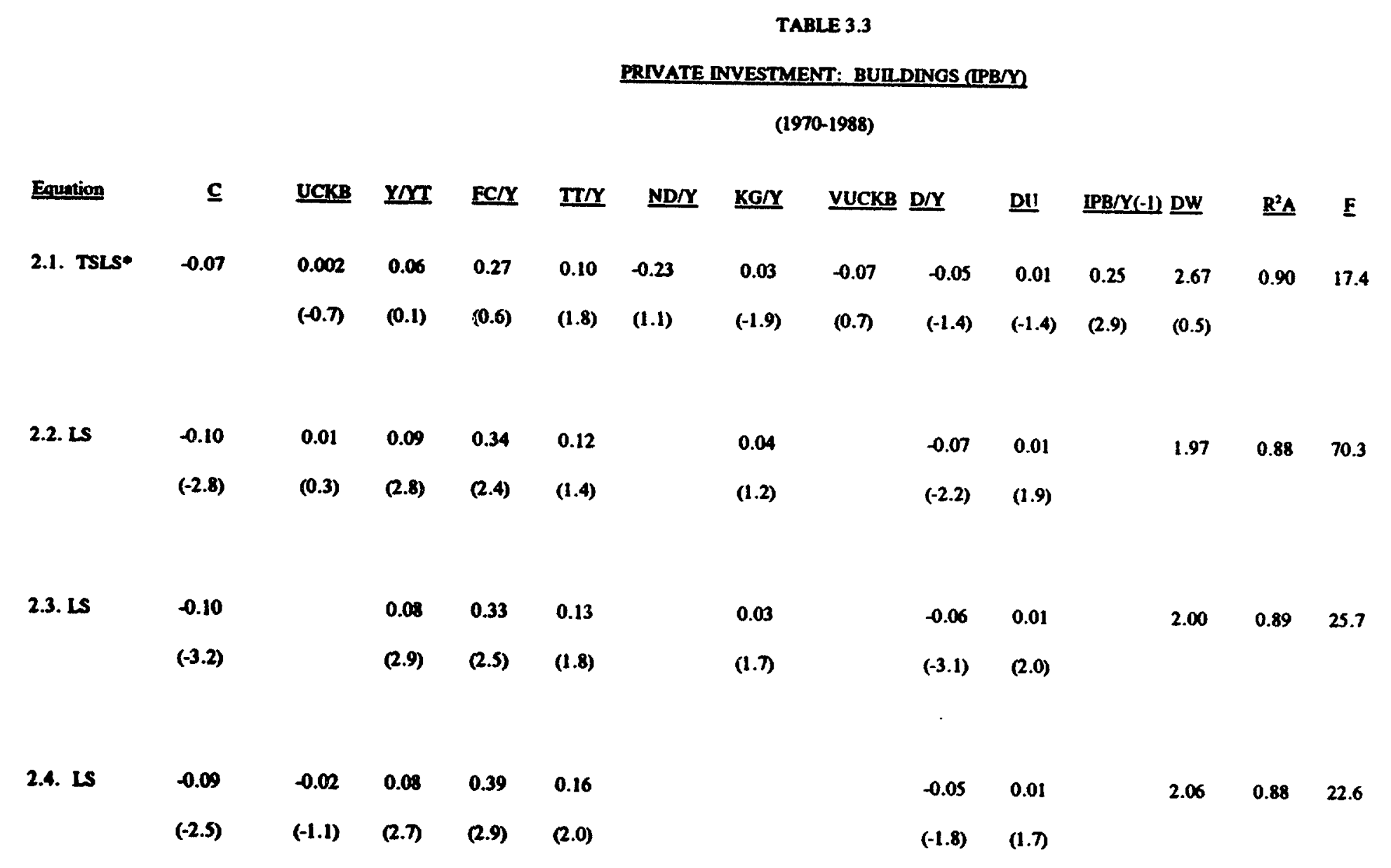

-Inetrumemalized variable: IPBY(-1) 
TABLE 3.4

PRIVATE INVESTMENT: MACHINERY AND EOUIPMENT APMIY

(1970-1988)

\begin{tabular}{|c|c|c|c|c|c|c|c|c|c|c|c|c|c|c|}
\hline Equation & c & uckM & yrar & $\mathrm{FC} / \mathrm{Y}$ & $\underline{\mathbf{T T} \boldsymbol{Y}}$ & ND/Y & KGIY & YUCKM & $\underline{D} / \mathbf{Y}$ & $\underline{\text { DU }}$ & $\operatorname{IPM} / \mathbf{Y}(-1)$ & DW & $\underline{\mathbf{R}^{2} \mathbf{A}}$ & $\underline{E}$ \\
\hline 3.1. TSLS & $\begin{array}{r}-0.23 \\
(-1.8)\end{array}$ & $\begin{array}{l}-0.01 \\
(-0.5)\end{array}$ & $\begin{array}{l}0.23 \\
(1.9)\end{array}$ & $\begin{array}{l}0.58 \\
(1.9)\end{array}$ & $\begin{array}{r}0.17 \\
(0.8)\end{array}$ & $\begin{array}{l}0.57 \\
(2.1)\end{array}$ & $\begin{array}{l}0.08 \\
(0.8)\end{array}$ & $\begin{array}{r}-0.08 \\
(-1.0)\end{array}$ & $\begin{array}{l}-0.17 \\
(-2.9)\end{array}$ & $\begin{array}{l}0.04 \\
(2.4)\end{array}$ & $\begin{array}{l}-0.57 \\
(-1.6)\end{array}$ & 2.26 & 0.92 & 21.0 \\
\hline 3.2. is & $\begin{array}{l}-0.08 \\
(-1.0)\end{array}$ & $\begin{array}{l}-0.02 \\
(-0.8)\end{array}$ & $\begin{array}{l}0.09 \\
(1.1)\end{array}$ & $\begin{array}{l}0.70 \\
(2.3)\end{array}$ & $\begin{array}{l}0.40 \\
(2.4)\end{array}$ & $\begin{array}{l}0.61 \\
(2.2)\end{array}$ & $\begin{array}{r}-0.03 \\
(-0.5)\end{array}$ & & $\begin{array}{l}-0.14 \\
(-2.3)\end{array}$ & $\begin{array}{l}0.02 \\
(1.7)\end{array}$ & & 1.79 & 0.91 & 23.2 \\
\hline 3.3. LS & $\begin{array}{r}-0.10 \\
(-1.1)\end{array}$ & & $\begin{array}{l}0.08 \\
(1.0)\end{array}$ & $\begin{array}{l}0.71 \\
(2.4)\end{array}$ & $\begin{array}{l}0.35 \\
(2.3)\end{array}$ & $\begin{array}{l}0.60 \\
(2.2)\end{array}$ & $\begin{array}{l}0.01 \\
(0.1)\end{array}$ & & $\begin{array}{l}-0.17 \\
(-3.6)\end{array}$ & $\begin{array}{l}0.02 \\
(1.6)\end{array}$ & & 1.62 & 0.91 & 27.4 \\
\hline 3.4. IS & $\begin{array}{r}-0.09 \\
(-1.1)\end{array}$ & $\begin{array}{l}-0.01 \\
(-0.6)\end{array}$ & $\begin{array}{l}0.09 \\
(1.1)\end{array}$ & $\begin{array}{r}0.63 \\
(2.4)\end{array}$ & $\begin{array}{l}0.38 \\
(2.4)\end{array}$ & $\begin{array}{l}0.57 \\
(2.3)\end{array}$ & & & $\begin{array}{l}-0.15 \\
(-2.6)\end{array}$ & $\begin{array}{l}0.02 \\
(1.8)\end{array}$ & & 1.75 & 0.91 & 28.4 \\
\hline 3.5. is & $\begin{array}{l}-0.01 \\
(-0.6)\end{array}$ & & & $\begin{array}{l}0.73 \\
(3.5)\end{array}$ & $\begin{array}{l}0.31 \\
(2.1)\end{array}$ & $\begin{array}{l}0.76 \\
(3.9)\end{array}$ & & & $\begin{array}{l}-0.17 \\
(-4.1)\end{array}$ & $\begin{array}{l}0.02 \\
(1.9)\end{array}$ & & 1.63 & 0.92 & 41.1 \\
\hline
\end{tabular}

-Instrumentalized variable: IPM/Y(-1) 


\section{CONCLUSIONS AND POLICY IMPLICATIONS}

This tinal section summarizes briefly the mair. findings on the determinants of private investment in Morocco and draws the relevant policy conclusions.

\subsection{Main Findings}

(i) Domestic and private capital formation have shown very pronounced fluctuations during the seventies and eighties in Morocco. After a period of relatively low investment rates in the early seventies, an investment boom raised domestic investment rates to $37 \%$ of GDP (and private investment rates to $24 \%$ ) during $1975-1977$. Subsequently, investment rates dropped to $23 \%$ of GDP and private investment rates to $17 \%$ during $1980 / 31$. The decline in real domestic investment ates to $17 \%$ and of real private investment rates to $13 \%$ of GDP in 1988 exceeds significantly the reduction in nominal investment rates, due to the depreciation of the real exchange rate between 1980 and 1985 , which raised significantly the price of capital goods relative to the GDP deflator.

(ii) Why did private investment fall during the adjustment period in the eighties? Our analysis suggests that growing uncertainty on future economic policy, as approximated by the debt/output ratio, is the major factor contributing to the investment decline. The rapid rise of the user cost of capital also seems to have driven down private investment. A more stringent credit policy and, to a lesser degree, the deterioration of the public capital stock (relative to GDP) also contributed to lower private capital formation.

(iii) Private investment in Morocco is significantly influenced by the cost of capital, the expected return on investment, the level of aggregate demand or capacity utilization, bank credit and the structure 
of financial markets, terms of trade shocks, the availability of public sector capital services, and uncertainty as reflected by the foreign debt/GDP ratio. Table 4.1 reflects the influence of the most important private investment determinants in Morocco, by showing the required changes in these determinants, each of which would increase the rate of private investment by 1 percentage point.

(iv) The level of foreign debt outstanding signals both the extent of the risk of future macroeconomic instability and relative price changes when policy uncertainty is prevalent and the more direct debt disincentive effect on investment stemming from the expectation of higher future taxes to service the debt. Our results show that the debt/GDP ratio is moderately significant in reducing Morocco's investment rate.

(v) The cost of capital relative to the price of output has increased significantly during the eighties in Morocco, due to a combination of higher taxes on profits, the real exchange rate depreciation, and the increase in real interest rates as administered nominal lending rates have been allowed to rise to levels reaching $14 \%$ in 1988 . Although the negative influence of the cost of capital on investment has a low magnitude, its effect on private capital formation seems to be growing every year as rising interest rates weaken the influence and extent of credit or quantity constraints.

(vi) The amount of bank credit to firms plays an essential role in an economy whose financial system is dominated by credit ceilings and quantity constraints, with interest rates plaving a secondary. although increasing, role in determining financial resource allocation. Not surprisingly, bank credit to firms has been a statistically and numerically important determinant of private investment in Morocco. However, because of the relatively declining role of credit constraints vis-a-vis the cost of capital, this relation is probably smaller in the present. 
TABLE 4.1

\section{CHANGES IN INVESTMENT DETERMINANTS}

REQUIRED TO RAISE PRIVATE INVESTMENT

To raise the private investment rate by 5 percentage points of GDP from the 1988 level of $13.3 \%$ to $18.3 \%$, which is slightly above the pre-adjustment level in 1982 , the combination of the following changes is required, each of them contributing to a recovery by one percentage point of GDP22:

* A decline in the external debt/GDP ratio by 6.7 percentage points (from $66.7 \%$ in 1988 to $60 \%$ ),

* A decline in the cost of capital of $12.5 \%$, or an incriase in the public capital stock/GDP ratio by 8.3 percentage points (from $76.3 \%$ in 1988 to $84.6 \%$ ),

* An increase in the bank credit/GDP ratio by 1.4 percentage points (from $23.7 \%$ in 1988 to $25.1 \%)$,

* An increase in the current/trend GDP ratio by 4.7 percentage points (from $99.2 \%$ to $103.9 \%$ ), * A gain in the terms of trade GDP ratio of 2 percentage points (from $1.1 \%$ in 1988 to $3.1 \%$ ).

(vii) Capacity utilization and the marginal product of capital both proniad by the ratic of curtent to trend GDP - are significant determinants of private investment in Morocco. This ratio, which reflects the ecoromy's business cycle, probably signals also the influence of an important financing source of private investment - retained profits - which are correlated with the cycle.

${ }^{22}$ Calculated from the averages of the coefficients of equations 1.5 and 1.6 in Table 3.1 . 
(viii) Gains from terms of trade are an important determinant of aggregate private investment, as opposed to net disbursements of foreign loans to the private sector. The former variable, which is often mentioned to have asymmetric effects on saving depending on its sign, suggests the importance of either an overreaction to transitory commodity price booms or the extent of foreign liquidity constraints, or both.

(ix) Public infrastructure, communications and transport services are very scarce though often underpriced in Morocco. This contributes to the high price of urban and industrial land, a major current constraint on private investment in the manufacturing sector. In our analysis we proxied the availability of infrastructure and communications by a measure of the capital stock stemming from public infrastructure investment. Although its significance suggests some role played by this constraint to private investment, its magnitude is quite small.

(x) Some differences with the results obtained for aggregate investment appear for investment levels disaggregated by sectors of origin. The role of the cost of capital is weaker at the sector than at the aggregate level. In general, construction invest sent (or investment in buildings) resembles more the results obtained for aggregate investment than those corresponding to investment in machinery and equipment do. While investment in buildings is influenced by the business cycle, investment in machinery and equipment depends on net foreign disbursements. In addition, puhlic inffastmeture exerts some influence on buildings investment, while it does not contribute to capital formation in machinery and equipment. The remaining variables (bank credit, terms of trade gains, and debt/output ratios) influence investment by sectors of origin in a similar way to aggregate private capital formation. 


\subsection{Policy Implications}

Various policy lessons can be drawn from our quantitative and qualitative assessment of private investment behavior in Morocco. They refer to fiscal policies, financial sector reform, public investment, management of terms of trade shocks, foreign debt policies, and foreign investment policies.

1. Public sector deficits have a strong negative impact on private capital formation in Morocco. They crowd out financing of private investment both directly (by reducing residual bank credit available to firms) and indirectly via higher real interest rates. A reduction of currently increasing public sector deficits is an essential prerequisite for achieving investment levels required for sustainable high growth rates. However, one should take into account that a more restrictive fiscal policy would probably induce a recessionary adjustment period and a real exchange rate depreciation, both affecting negatively private investment during the adjustment phase.

2. The current structure of financial markets constitutes a significant hindrance to an efficient resource allocation, and probably also affects the aggregate level of private investment. Elimination of interest rate controls, credit ceilings, sectoral allocation of credit, and non-competitive access of the public sector to bank credit are among the main features of financial sector reform. Even if such a reform does not increase total resources for investment, ${ }^{23}$ it could contribute significantly to the efficiency of financial intermediation, resource allocation, and hence to growth.

3. Public infrastructure, transport and communication networks are essential factors contributing to the provision of goods and services by the private sector. Not surprisingly, the scarcity and frequent underpricing of these services affect negatively private investment in Morocco. Therefore fiscal

\footnotetext{
${ }^{20}$ Private saving in Morocco is insensitive to interest rates, as the results in a related paper suggest (Schmidt-Hebbel and Müller, 1990).
} 
budgeting should program the required resources for significant improvements in the quantity and quality of public fixed capital, the latter achieved by a systematic evaluation of public sector projects.

4. Terms of trade gains and losses tend to be reflected by movements in investment rates. This procyclical behavior of investment rates could be dampened by a commodity export price or returns management policy for major export commodities (phosphates), insulating domestic absorption from exante perceived transitory price shocks by making use of a special stabilization fund.

5. Morocco's high foreign debt increases uncertainty perceived by domestic investors. A prudent and consistent debt transformation and servicing policy could overcome in the medium term the negative disincentive effects of the debt on private investment. A debt and debt service reduction agreement between Morocco and its commercial creditors would help considerably to reduce uncertainty stemming from the debt overhang.

6. Finally, foreign investment faces multiple barriers in Morocco, most of them related to the Moroccanization law of 1973. A reform of this law would generate a powerful incentive for foreign investment inflows, which cculd constitute important complementary sources of financing for highly indebted countries, like Morocco, which face stringent foreign resource constraints. 


\section{REFERENCES}

Bernanke, B. (1983): "Irreversibility, Uncertainty, and Cyclical Investment, "Quarterly Journal of Economics.

Bertola, G. (1989): "Irreversible Investment," mimeo, Princeton University.

Bizer, D. and D. Sichel (1988): "Irreversible Investment: An Empirical Investigation," mimeo.

Chhibber, A. and N. Shafik (1990): "Does Devaiuation Hurt Private Investment? The Indonesian Case", WPS \# 418, Washington, D.C.

Dailami, M. (1990a): "Financial Policy and Corporate Investment in Imperfect Capital Markets: the Case of Korea", World Bank WPS \# 409, Washington, D.C.

(1990b): "Policy Changes that Encourage Private Investment in Colombia", World Bank WPS \# 226, Washington, D.C.

and M. Walton (1989):" Private Investment, Government Policy and Foreign Capital in Zimbabwe", World Bank WPS \# 248, W: shington, D.C.

De Melo, J. and J. Tybout (1990): "The Effects of Financial Liberalization on Savings and Investment in Uruguay", Economic Development and Cultural Change.

Easterly, W., Rodriguez, C.A. and K. Schmidt-Hebbel (1989): "Research Proposal: The Macroeconomics of Public Sector Deficits", mimeo, The World Bank, Washington, D.C.

Easterly, W. and and K. Schmidt-Hebbel (1991): "The Macroeconomics of Public Sector Deficits: a synthesis", paper presented at the World Bank Conference on Macroeconomics of Public Sector Deficits, Washington, D.C, June.

Faini, R. and Pigato, M. (1989): "Morocco: The Cost of Capital", mimeo, The World Bank, Washington, D.C..

Faini, R. and J. de Melo (1990): "Adjustment, Investment, and the Real Exchange Rate in Developing Countries", Economic Policy.

Greene, J. and D.Villanueva (1991): "Private Investment in Developing Countries: An Empirical Analysis", IMF Staff Papers, March.

Kahn, M. and C. Reinhart (1989): "Private Investment and Economic Growth in Developing Countries", IMF Staff Papers

Musalem, A. (1989): "Private Investment in Mexico: an Empirical Analysis", World Bank WPS \# 183, Washington, D.C. 
Pfeffermann, G.P. and Madarassy, A. (1989): "Trends in Private Investment in Thirty Developing Countries", Discussion Paper No.6, International Finance Corporation, Washington, D.C..

Pindyck. R. (1988): "Irreversihle Investment, Capacity Choice, and the Value of the Firm", American Economic Review 78, pp. 969-85.

(1989): "Irreversibility, Uncertainty, and Investment," mimeo.Rodrik, D. (1989): "Policy Uncertainty and Private Investment in Developing Countries", NBER Working Paper No. 2999.

Schmidt-Hebbel, K. (1987): "Foreign Shocks and Macroeconomic Adiustment in Small Open Economies", M.I.T. Ph.D. Dissertation, Cambridge, Massachusetts.

Schmidt-Hebbel, K. (1990): "External Debt, Macroeconomic Adjustment and Growth in Brazil", mimeo, The World Bank, Washington, D.C..

Schmidt-Hebbel, K. and S. Vatnick (1990): "Macroeconomic Effect of Alternative Debt Transformation Schemes for Brazil: A Simulation Analysis", mimeo, The World Bank, Washington, D.C..

Schmidt-Hebbel, K. and T. Müller (1990): "Private Investment and Saving in Morocco", mimeo, The World Bank, Washington, D.C.

Serven, L. and A. Solimano (1990): "Private Investment and Macroeconomic Adjustment in LDCs: Theory, Country Experiences, and Policy Implications", World Bank WPS $\# 606$, Washington, D.C..

Solimano, A. (1989): "Investment Behavior and Macroeconomic Adjustment: An Empirical Analysis for Chile", World Bank WPS \# 212, Washington, D.C.

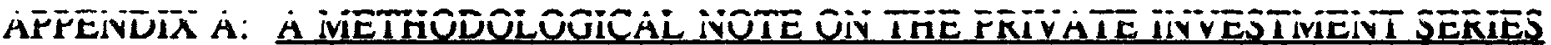

Three major problems arise in deriving time series for private investment in Morocco. First, no consistent time series are available for public enterprise investment. As private sector investment has to be derived residually by deducting public sector figures from investment from domestic investment, the con-jefined nrivate sector includes public enterprises. Thus, total grnss domestic investment (and national saving) could only be broken down into two categories: general government ${ }^{24}$ and private sector (including public enterprises). In this papers, the words public and private refer to this particular breakdown.

${ }^{24}$ General government is defined as the aggregate of the central government (budget general, budgets annexes, comptes speciaux du tresor), local administrations, public non profit organizations (e.g. universities, hospitals), and the social security system. 
Second, investment deflators are not published for Morocco and therefore had to be estimated. For that purpose, we chose separate deflators for the two main investment categories (essentially machinery and equipment, and construction). Because of the different composition of private and public investment, their deflators do not follow the same evolution.

Third, it is difficult to reconcile government data coming from different sources, i.e. the national accounts and the budget. Fixed capital formation of the government is only published in the national accounts, where it is defined for general government. The series for the government deficit comes from budget data, thus including only central government. Therefore, general government saving had to be estimated using an ad hoc assumption on the deficit of local governments and social security.

Some comments on the methodological problems related to the first two problems follow.

\section{On Public and Private Investment}

The analysis of private investment in the eighties, however, and the identification of the variables which affect private investment behavior in Morocco are not affected significantly by these shortcomings in data availability. The conclusions presented in this paper would be affected only if the following three conditions were simultaneously met. First, the share of public enterprise investment in non-government investment is large. Second, the share of public enterprise investment in non-government investment varies widely over time. Third, the behavior of most public enterprises with respect to investment decisions is different from private enterprises' behavior.

From the limited information available, it can be asserted that these three conditions are not met simultaneously. First, the share of public enterprise investment in total non-government investment is not large; according to the only data available it was $28 \%$ for the period 1980-82. Second, partial information on major public enterprises (ONE, ONEP, ONCF, ONPT) indicates that their share in nongovernment investment has probably decreased from about $11 \%$ in 1982 to 6-7\% in 1987, and picked up to $10 \%$ in 1988 . These variations do not seem to be significant enough to change the conclusions of the analysis. Finally, an important number of public enterprises, such as OCP and RAM, make their investment decisions on the basis of market signals or constraints, even if some of them behave in a

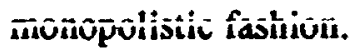

In the absence of complete data, an important question remains: Can "strictly private" in /estment have increased between 1982 and 1988 as a share of GDP, while non-government (public and private enterprise) investment fell? For the decline in private investment not to have happened, non-government investment would have had to fall by very large amounts between 1982 and 1988 . For strictly private investment to remain constant as a share of GDP (in real terms) during 1982-88, public escerprise (PE) investment would have had to fall in teal terms from 4.8\% of GDP in 1982 to 1.0\% of GDP in 1986-88. This means that the level of PE investment at current prices would have had to fall from 5.1 billion Dirhams in 1982 to 2.2 billion dirhams in 1988. It appears that the investment of four major public enterprises (ONE, ONEP, ONCF, ONPT) in 1988 already amounts to 2.9 billion dirhams. For private investment to increase as a share of GDP (in real terms) the fall in public enterprise investment would have had to be even more dramatic. We assume implicitly in our analysis that the relative shares of private investment and PE investment remained constant within total non-government investment since 1982. That would still imply a fall in the ratio of public enterprise investment to GDP (in real terms), from $4.8 \%$ in 1982 to $3.7 \%$ in 1988 . 


\section{(ii) Qn Investment Deflators}

Total (and government) fixed capital formation appears in the Moroccan national accounts by sectors of origin that can be aggregated into machinery and equipment, buildings, and agriculture. For each of these categories, separate price indices have been estimated. The investment deflators are then calculated as weighted averages of the individual price indices.

The price index for machinery and equipment is a weighted average of a price index for imported capital goods (the unit value of manutactured exports by the G-5 to developing countries, MUV, converted into DRH) and a deflator for domestic value added of the manufacturing sector. We assumed weights of .8 for the former and .2 for the latter.

For buildings, as well as for agriculture, deflators are taken from the national accounts.

\section{APPENDIX B: THE REAL USER COST OF CAPITAL}

This Appendix has been adapted from a note by Faini and Pigato (1989). The latter calculates the nominal user cost of capital, whereas we use the real user cost in the regressions.

The cost of capital in Morocco has been greatly affected by a complex system of investment incentives and tax provisions aimed at redressing regional imbalances. Three zones are distinguished: (a) the Casablanca area (zone 1); (b) the Fez area (zone 2); and (c) the Tanger area (zone 3). In the 1983 Investment Code, the Fez and Tanger areas have been aggregated together. The three areas cover the quasi totality of the investment expenditures approved under the code. The Codes distinguish between extension and creation investments. The following discussion focuses on the impact of the incentive decisions in new plants only.

The 1973 Code. Its main provisions were: (a) custom duty and indirect tax exemption on imports of investment and intermediate goods; (b) 50\% corporate tax exemption in Zone 2 and 3 and accelerated depreciation allowances in Zone 1 for new firms. For existing firms, the corporate tax exemption is grant'sd for a ten year period starting from their creation date; (c) tive year exemption on the patent tax (basically a capital levy); and d) $2 \%$ interest rate rebates on BNDE loans.

The 1983 Code. Its main provisions are: (a) custom duty and indirect tax exemption on imports of investment and intermediate goods. The exemption is fairly general. Only new firms which are located in the Casablanca area are not entitled to it: (h) a $50 \%$ mmnrate tar evomntion for firms in zones 2 and 3; (c) accelerated depreciation allowances are abolished; and (d) interest rate rebates are eliminated for firms located in zone 1.

The 1989 Code. Its main provisions are: new firms which are located in zones 2 and 3 may choose between: (a) a $50 \%$ corporate tax exemption; and (b) accelerated depreciation allowances equal to twice the value normally allowed to new firms.

\section{The Real User Cost of Capital}

If interest payments are fully tax-deductible, as in the Moroccan context, the user cost of capital (uck) is equal to:

$$
u c k=q\left(r(1-t)+d-\pi^{c}\right) / p
$$


where $q$ is the price of investment goods, $r$ is the lending interest rat, $t$ is the corporate tax rate, $d$ is the depreciation rate, $\pi^{\circ}$ is the expected inflation of the investment goods price $q$, and $p$ is the GDP deflator. incentives.

The value of $q$ has been computed taking into account the whole system of fiscal and financial

Therefore :

$$
q=q m(1-t s) /(1-t)
$$

where $\mathrm{gm}$ is the market price of investment goods, and ts is the present discounted value of present and future tax savings from fiscal depreciation allowances. With linear depreciation allowances ts is equal to:

$$
t s=t * 1 / T[1-(1 / 1+r(1-t)) * T] * 1 / r(1-t) 1 / r(1-t)
$$

where $\mathrm{T}$ is the relevant capital gonds life length.

Two investment sectors are considered: construction and equipment. $T$ is 20 (10) for construction (equipment) under normal depreciation schedules. With accelerated depreciation, the values of $\mathrm{T}$ are $50 \%$ lower. Thus,

The lending rate charged by BNDE has been used in the empirical implementation of the model.

$$
r=(r l-r e b) *(1+t p s)
$$

where $\mathrm{rl}$ is the nominal BNDE lending rate, reb is the 2\% rehate allowed in zones 1 and 2 from 1973 to 1986 and in zone 3 from 1973 to 1982 , and tps is the tax "sur les provisions et services", a patent tax; this tax rate has been equal to $12 \%$ throughnut the period.

A uniform value of $5 \%$ has been assumed for the rate of depreciation. A basic value of $48 \%$ has been used for the corporate tax rate. This rate his been increased by the PSN tax (a National Solidarity tax) atter 1980 and allowance has been made for the various tax holidays in zones 2 and 3.

Finally, the deflator of private fixed investment has been used as the price of investment goods. Expectations on future inflation are assumed to be a simple average of static expectations and perfect foresight.

$$
\pi^{e}=(1 / 2)\left(q / q_{-1}-1\right)+(1 / 2)\left(q_{+1} / q-1\right)
$$

Three indices of the cost of capital, one for each zone are calculated. Then they are aggregated, using 1980 weights, to yield the final estimate of the real user cost of capital nresented in Appendix C. The user cost of capital for machinery and equipment UCKM (and for buildings UCKB) is calculated similarly to UCK, using the deflator for machinery and equipment (buildings) for $\mathbf{p}$. 


\section{APPENDIX C: MOROCCO DATA SERIES (1970-1988)}

Table C.1

SAVING-INVESTMENT BAI ANCF

(\% of GDP, at current prices)

\begin{tabular}{|c|c|c|c|c|c|c|c|c|}
\hline & $\begin{array}{l}\text { Private } \\
\text { FCF }\end{array}$ & $\begin{array}{c}\text { General } \\
\text { Government } \\
\text { FCF } \\
\end{array}$ & $\begin{array}{l}\text { Changes } \\
\text { in } \\
\text { Stocks }\end{array}$ & $\begin{array}{c}\text { Gross } \\
\text { Domestic } \\
\text { Investment }\end{array}$ & $\begin{array}{l}\text { Private } \\
\text { Saving }\end{array}$ & $\begin{array}{c}\text { General } \\
\text { Government } \\
\text { Saving }\end{array}$ & $\begin{array}{c}\text { Current } \\
\text { Account } \\
\text { Deficit }\end{array}$ & $\begin{array}{l}\text { Total } \\
\text { Saving }\end{array}$ \\
\hline 1970 & 10.6 & 5.2 & 4.6 & 20.4 & 15.7 & 1.7 & 3.0 & 20.4 \\
\hline 1971 & 10.1 & 5.6 & 4.0 & 19.7 & 15.6 & 2.7 & 1.3 & 19.7 \\
\hline 1972 & 9.5 & 4.8 & 2.2 & 16.5 & 16.4 & 1.0 & -0.9 & 16.5 \\
\hline 1973 & 10.3 & 3.9 & 4.3 & 18.6 & 18.2 & 2.0 & -1.6 & 18.6 \\
\hline 1974 & 11.8 & 3.7 & 7.7 & 23.2 & 26.1 & 0.0 & -2.9 & 23.2 \\
\hline 1975 & 17.5 & 8.7 & 0.5 & 26.6 & 21.2 & -0.4 & 5.8 & 26.6 \\
\hline 1976 & 20.6 & 10.7 & -2.0 & 29.2 & 21.8 & -6.4 & 13.8 & 29.2 \\
\hline 1977 & 22.4 & 11.3 & 3.0 & 36.6 & 24.7 & -3.7 & 15.7 & 36.6 \\
\hline 1978 & 19.8 & 6.5 & 0.7 & 26.9 & 21.3 & -4.0 & 9.6 & 26.9 \\
\hline 1979 & 17.4 & 7.8 & 0.7 & 25.9 & 18.6 & -1.8 & 9.1 & 25.9 \\
\hline 1980 & 16.7 & 5.5 & 2.0 & 24.2 & 21.2 & -4.5 & 7.5 & 24.2 \\
\hline 1981 & 18.5 & 7.5 & 0.2 & 26.1 & 20.8 & -6.9 & 12.2 & 26.1 \\
\hline 1982 & 19.7 & 7.6 & 0.9 & 28.2 & 20.7 & -4.8 & 12.3 & 28.2 \\
\hline 1983 & 18.5 & 6.0 & -0.5 & 24.0 & 22.8 & -6.1 & 7.3 & 24.0 \\
\hline 1984 & 18.3 & 4.8 & $2.2 \&$ & 25.3 & 22.4 & -6.4 & 9.3 & 25.3 \\
\hline 1985 & 17.8 & 5.4 & 4.0 & 27.1 & 23.2 & -4.3 & 8.2 & 27.1 \\
\hline 1986 & 16.5 & 4.9 & 3.1 & 24.5 & 22.4 & -0.5 & 2.5 & 24.5 \\
\hline 1987 & 16.0 & $4 . \overline{0}$ & $\hat{2} .6$ & 22.6 & 23.2 & -1.1 & 1.1 & $\hat{2} \hat{2} .0$ \\
\hline 1988 & 16.3 & 4.1 & 3.3 & 23.6 & 23.9 & -0.1 & -0.2 & 23.6 \\
\hline
\end{tabular}

Sources:

The data on fixed-capital formation (FCF) and changes in stocks are from National Accounts. General government saving is calculated as the sum of central government overall balance, before debt relief (from Treasury sources) and its FCF. The current account deficit (before debt relief) is from the Balance of Payments. Finally, private saving is obtained residually. 
Table C.2

PRIVATE FIXED-CAPITAL INVESTMENT BY SECTOR OF ORIGIN (\% of GDP, at constant 1980 prices)

\begin{tabular}{|c|c|c|c|c|c|}
\hline & $\begin{array}{c}\text { Machinery } \\
\text { and Equipment }\end{array}$ & Buildings & $\begin{array}{l}\text { Public } \\
\text { Work: }\end{array}$ & Other & $\begin{array}{l}\text { Private } \\
\text { Fixed-Capital } \\
\text { Investment }\end{array}$ \\
\hline 1970 & 6.1 & 3.5 & 3.3 & 0.8 & 13.7 \\
\hline 1971 & 5.4 & 4.1 & 3.0 & 0.7 & 13.3 \\
\hline 1972 & 5.2 & 3.9 & 2.9 & 0.8 & 12.9 \\
\hline 1973 & 5.9 & 4.2 & 2.5 & 0.8 & 13.4 \\
\hline 1974 & 7.8 & 4.1 & 2.7 & 0.8 & 15.3 \\
\hline 1975 & 11.0 & 6.0 & 5.0 & 0.5 & 22.6 \\
\hline 1976 & 11.7 & 6.7 & 5.2 & 0.5 & 24.1 \\
\hline 1977 & 12.9 & 6.4 & 4.7 & 0.4 & 24.4 \\
\hline 1978 & 9.6 & 7.3 & 3.3 & 0.5 & 20.6 \\
\hline 1979 & 8.4 & 6.1 & 2.9 & 0.4 & 17.7 \\
\hline 1980 & 7.3 & 5.7 & 2.8 & 0.9 & 16.7 \\
\hline 1981 & 6.8 & 6.0 & 3.2 & 0.7 & 16.8 \\
\hline 1982 & 7.8 & 5.5 & 3.2 & 0.6 & 17.1 \\
\hline 1983 & 5.5 & 5.5 & 3.4 & 0.6 & 14.9 \\
\hline 1984 & 5.6 & 4.9 & 3.0 & 0.7 & 14.2 \\
\hline 1985 & 5.3 & 4.7 & 3.0 & 0.7 & 13.7 \\
\hline 1986 & 5.3 & 4.4 & 2.8 & 0.8 & 13.3 \\
\hline 1987 & 5.0 & 4.9 & 2.6 & 0.9 & 13.4 \\
\hline 1988 & 4.7 & 5.3 & 2.6 & 0.7 & 13.3 \\
\hline
\end{tabular}

Source: National Accounts and World Bank estimates for deflators. 
Table C.3

\section{REAL USER COST OF CAPITAL AND ITS MOVING VARIANCE}

$\begin{array}{lllllll} & \text { UCK } & \text { UCKM } & \text { UCKB } & \text { VUCK } & \text { VUCKM } & \text { VUCKB } \\ 1970 & 8.5 \% & 8.4 \% & 9.5 \% & 0.0008 & 0.0021 & 0.0009 \\ 1971 & 8.7 \% & 8.9 \% & 9.3 \% & 0.0011 & 0.0151 & 0.0063 \\ 1972 & 8.8 \% & 11.8 \% & 8.1 \% & 0.0512 & 0.0536 & 0.0536 \\ 1973 & -2.1 \% & -0.7 \% & -2.6 \% & 0.0481 & 0.0623 & 0.0451 \\ 1974 & -0.5 \% & -2.0 \% & 0.4 \% & 0.0326 & 0.0328 & 0.0324 \\ 1975 & 5.4 \% & 5.5 \% & 5.3 \% & 0.0349 & 0.0306 & 0.0557 \\ 1976 & -2.8 \% & 1.5 \% & -8.2 \% & 0.0432 & 0.0195 & 0.0774 \\ 1977 & -4.4 \% & 1.3 \% & -13.0 \% & 0.0276 & 0.0190 & 0.0395 \\ 1978 & 2.1 \% & 5.4 \% & -3.3 \% & 0.0337 & 0.0170 & 0.0652 \\ 1979 & 3.3 \% & 3.2 \% & 2.8 \% & 0.0293 & 0.0633 & 0.0252 \\ 1980 & -3.5 \% & -9.0 \% & -0.2 \% & 0.0318 & 0.0585 & 0.0136 \\ 1981 & -3.5 \% & -9.4 \% & 0.1 \% & 0.0219 & 0.0343 & 0.0247 \\ 1982 & -8.1 \% & -16.5 \% & -5.3 \% & 0.0244 & 0.0511 & 0.0233 \\ 1983 & -9.1 \% & -21.9 \% & -4.3 \% & 0.0686 & 0.1000 & 0.0667 \\ 1984 & 5.9 \% & 1.5 \% & 9.4 \% & 0.0930 & 0.1376 & 0.0802 \\ 1985 & 13.3 \% & 10.8 \% & 14.8 \% & 0.0782 & 0.1073 & 0.0593 \\ 1986 & 24.9 \% & 27.4 \% & 23.7 \% & 0.0558 & 0.0821 & 0.0398 \\ 1987 & 25.3 \% & 29.2 \% & 22.6 \% & 0.0165 & 0.0144 & 0.0168 \\ 1988 & 21.6 \% & 25.7 \% & 19.8 \% & 0.0173 & 0.0166 & 0.0135\end{array}$

Definitions and Sources:

UCK Real user cost of capital for total private investment. See Appendix B for a detailsd description.

UCKM Real user cost of capital for investment in machinery and equipment.

UCKB Real user cost of capital for investment in buildings.

VUCK Moving variance of the real user cost of capital for total private investment. Variance calculated over three periods (last, present, next).

YICKM Idem, for investment in machinery and equipment.

VUCKB Idem, for investment in buildings. 
Table C. 4

Qther Determinants of Private Investment

$(\%)$

$\begin{array}{lllllll} & \mathrm{Y} / \mathrm{YT} & \mathrm{FC} / \mathrm{Y} & \underline{\mathrm{TT} / \mathrm{Y}} & \underline{\mathrm{ND} / \mathrm{Y}} & \underline{\mathrm{KG} / \mathrm{Y}} & \underline{\mathrm{D} / \mathrm{Y}} \\ 1970 & 100.6 & 14.3 & -0.57 & 0.50 & 49.6 & 17.7 \\ 1971 & 101.4 & 13.8 & -0.18 & 0.72 & 52.4 & 19.9 \\ 1972 & 099.1 & 15.0 & -0.79 & -0.03 & 57.4 & 21.7 \\ 1973 & 98.0 & 15.7 & -0.36 & -0.26 & 60.7 & 20.4 \\ 1974 & 96.8 & 14.1 & 3.22 & 1.36 & 62.3 & 18.7 \\ 1975 & 99.3 & 16.8 & 4.20 & 1.42 & 61.1 & 17.2 \\ 1976 & 106.2 & 19.1 & 0.19 & 1.58 & 64.1 & 19.1 \\ 1977 & 108.7 & 19.0 & -0.73 & 5.2 & 70.9 & 25.5 \\ 1978 & 106.1 & 21.1 & -0.98 & 3.10 & 79.9 & 40.2 \\ 1979 & 106.1 & 21.4 & 0.35 & 3.11 & 80.3 & 43.2 \\ 1980 & 105.0 & 21.3 & 0.00 & 1.25 & 82.7 & 50.0 \\ 1981 & 97.4 & 22.5 & -0.98 & 0.28 & 88.2 & 53.6 \\ 1982 & 102.0 & 22.6 & -1.58 & 2.63 & 84.4 & 53.8 \\ 1983 & 96.8 & 24.6 & -1.62 & 1.21 & 89.3 & 63.3 \\ 1984 & 96.4 & 24.8 & -1.74 & 1.59 & 87.9 & 66.0 \\ 1985 & 97.9 & 24.7 & -1.57 & 1.25 & 84.0 & 67.6 \\ 1986 & 101.3 & 23.3 & -0.13 & 1.80 & 72.2 & 72.9 \\ 1987 & 94.1 & 24.9 & 0.58 & 0.80 & 83.2 & 71.0 \\ 1988 & 99.2 & 23.7 & 1.10 & 0.45 & 76.3 & 66.7\end{array}$

VMT Datin nf current to trend real ODP (Source of current GDP: National Accounts). Trend GDP (YT) is defined at the fitted eeries of the determiniatic irend regreation: $Y=a \exp (b t)$, where $t$ is time, and $a, b$ are coefficients.

FC/Y Ratio of firm credit to GDP. FC is total thon, medium and long term credit extended by deposit benks and apecialized finuncial insitutions to firm (Sounce: Anmul Report, Bank al Maghrib).

TT/Y Ratio of the Terms of Trade Adjuament wo real GDP. TT is defined as the difference between nominal exports of GNFS (XN) deflated by the import deflator and exports at constant prices: XN/PM - XN/PX $=$ XR (PX/PM-1). (Source: National Accounts).

ND/Y Ratio of net foreign diabunements to private and Public enterprises (of Public and publicly guarenteed debt) to GDP. (Source: DRS, World Bank).

KO/Y Ratio of general government capital stock to GDP. KG is calculated by cumulating real investment, asauming an initin government capitul to GDP ratio of .5 in 1968 and a depreciation rate of $3 \%$ per annum (Source: National Accountu).

D/Y Ratio of extomal debt to GDP at conetant prices and conatant exchange rate. D is total external medium and long torm debt, including MF (Source: DRS, World Bank). 
Itte

WPS771 Macroeconomic Structure and Policy in Zimbabwe: Analysis and Empirical Model (1965-88)

WPS772 Macroeconomic /djustment to Oil Shocks and Fiscal Reform:

Simulations for Zımbabwe, 1988-95

WPS773 Are Ghana's Roads Paying Their Way? Assessing Road Use Cost and User Charges in Ghana

WPS774 Agricultural Pricing Systems and Transportation Policy in Africa

WPS775 The Macroeconomics of Public Sector Deficits: A Synthesis

WPS776 Enforcement of Canadian "Unfair" Trade Laws: The Case for Competition Policies as an Antidote for Protection

WPS777 Do the Benefits of Fixed Exchange Rates Outweigh Their Costs? The Franc Zone in Africa

WPS778 A Dynamic Bargaining Model of Sovereign Debt

WPS779 Special Programme of Research, Development and Research Training in Human Reproduction

WPS780 Optimal User Charges and Cost Rccovery for Roads in Developing Countries

WPS781 The Korean Consumer Electronics Industry: Reaction to Antidumping Actions

WPS782 The Economic Effects of Widespread Application of Antidumping Duties to Impon Pricing

WPS783 The Origins and Evolution of Antidumping Regulation

WPS784 Chemicals from Poland: A Tempest in a Teacup
Author

Date

Contact

for paper

\section{Ibrahim A. Elbadawi}

Klaus Schmidt-Hebbel

September 1991

S. Jonnakuty 39074

Ibrahim A. Elbadawi

Klaus Schmidt-Hebbel

September 1991

S. Jonnakuty 39074

Reuben Gronau

September 1991

J. Francis 35205

Mark Gersovitz

October 1991

B. Gregory 33744

William Easterly

Klaus Schmidt-Hebbel

October 1991

R. Martin 39065

Mark A. Dutz

October 1991

N. Artis

37947

October 1991

Shantayanan Devarajan Dani Rodrik

A. Bhalla 37699

Eduardo Fernandez-Arias

October 1991

Janet Nassim

October 1991

S. King-Watson 31047

O. Nadora 31019

Ian G. Heggie

October 1991

P. Cook

33462

Taeho Bark

October 1991

N. Artis 37947

October 1991

N. Artis 37947

Sumana Dhar

J. Michael Finger

October 1991

N. Artis 37947

Andrzej Olechowski

October 1991

N. Artis

37947 
PRE Working Paper Series

Inte

WPS785 Huw Did the Asian Cuuntries Avoid the Debt Crisis?

WPS786 Fiscal Policy for Managing Indonesia's Environment

WPS787 Private Investment Uride: Macroeco. nomic Adjustment in Morocco

WPS788 How Expectations Affect Reform Dynamics in Developing Countries
Author

islllat Husain

Sadiq Ahmed

Klaus Schmidt-Hebbel

Tobias Muller

Francesco Daveri
Date

Ocivuel issi

October 1991

October 1991

October 1991
Contact

for paper

S. King-Watson 31047

B. Prasertwaree 82477

S. Jonnakuty 39074

S. Jonnakuty 39074 